\title{
Octospora mnii (Pezizales), a new ascomycete on the persistent protonema of Rhizomnium punctatum
}

\author{
PETER DÖBBELER and EVA FACHER
}

\begin{abstract}
DÖBBELER, P. \& FACHER, E. 2014: Octospora mnii (Pezizales), a new ascomycete on the persistent protonema of Rhizomnium punctatum. - Karstenia 54: 49-56. HELSINKI. ISSN 0453-3402.

Octospora mnii (Pezizales) is a biotrophic parasite of operculate discomycetes and is described here for the first time. This novel species infects the persistent protonema of Rhizomnium punctatum (Mniaceae, Bryopsida). It has exceptionally small, inconspicuous, scattered apothecia that form between the protonemal filaments. The hyphae develop large, septate, thick-walled appressoria that are closely attached to the filaments of the caulonema and chloronema. An infection peg perforates the host cell wall and develops an intracellular haustorium. The host belongs to a family hitherto not recorded as a substrate for octosporaceous fungi. Apothecia have been repeatedly observed during the autumn over the last few years in the same gorge near Starnberg, in Upper Bavaria. Octospora mnii is one of the few fruit-body forming ascomycetes that appear to be restricted to the protonemata of bryophytes.
\end{abstract}

Key words: appressoria, biotrophic parasites, bryophilous fungi, muscicolous fungi, protonema as substrate, Mniaceae

Peter Döbbeler \& Eva Facher, Ludwigs-Maximilians-Universität München, Fakultät für Biologie, Systematische Botanik und Mykologie, Menzinger Str. 67, 80638 München, Germany; e-mail:doebbeler@lrz.uni-muenchen.de

\section{Introduction}

Octospora Hedw. and the related genera Lamprospora De Not., Neottiella (Cooke) Sacc., Octosporella Döbbeler and Filicupula Y.J.Yao \& Spooner form a well-defined group of biotropic ectoparasites on mosses and liverworts that is quite distinct from other pezizalean ascomycetes. This group often has large, reddish or orange coloured apothecia, and colourless, thick-walled hyphae that develop elaborate infection structures rarely found elsewhere among the bryophilous fungi. The extracellular cushion-like appressoria located on the leaf, stem or rhizoid cells form intracellular haustoria via infection pegs. As in other highly adapted parasites, these fungi are usually restricted to a single host species or groups of related host species. Many of these parasitic fungi occur on soil-inhabiting acrocarpous mosses that arise from an underground rhizoidal system, but they also colonize pleurocarps and foliose and thallose hepatics. The host species are found in a wide range of environmental conditions and on substrates varying from dung, soil and rock to bark and wood. Even epiphyllous hepatics occurring on the living leaves of vascular plants in tropical rain forests may be infected. Over 80 critically studied Octospora taxa have been recorded from Europe 
alone, and more than half of them have been described since 1970 (Benkert 2007). We describe a distinct novel species that infects the persistent protonema of a moss belonging to a family previously not identified as a host for octosporaceous fungi.

\section{Material and methods}

Protonematal mats were collected randomly in the field. Back in the laboratory, the material was cleaned with tap water and screened for the presence of apothecia (magnification $\times 40$ ). Dry herbarium specimens were thoroughly wetted to enable effective screening. For the study of hyphal characters, the felt-like protonema immediately surrounding an ascoma was excised, carefully pulled apart and stained with lactophenol-cottonblue. All measurements were carried out on material prepared either with tap water or heated lactophenol-cottonblue (hyphae and infection structures). Ascomata, hymenial elements, and hyphal features were drawn in the medium indicated in the figure legends. Extreme values of measured structures are given in brackets.

\section{Octospora mnii Döbbeler \& Facher, sp. nova}

\section{MycoBank no.: MB810664}

Apothecia variabilia, 300-600 $\mu \mathrm{m}$ longa et 200 $600 \mu \mathrm{m}$ lata, primo subdoliiformia, demum disco plano, sine margine protrudenti, vix colorata vel flavida. Excipulum in parte inferiore textura epidermoidea ad textura globulosa, cellulae usque ad $35 \mu \mathrm{m}$ longae, in parte superiore textura porrecta, cellulae 4-8 $\mu \mathrm{m}$ latae, cyanophilae. Paraphyses filiformes, sine ramificationibus, tenui-tunicatae, apicaliter saepe dilatatae, 5-8 $\mu$ m latae. Asci 150-230 × 15-19 $\mu$ m, unitunicati, cylindrici, plerumque octo-spori. Ascosporae 14-17 × 10-13 $\mu \mathrm{m}$, subglobosae ad ovoideae, incoloratae, una gutta magna praeditae, episporio sutiliter aspero, cyanophilo, in ascis plerumque uni-seriatae. Hyphae 3-5 um latae, incoloratae, appressoria et haustoria

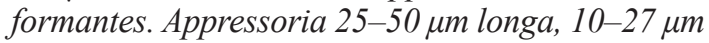
alta et 21-26 $\mathrm{mm}$ lata, uni-vel biseptata. Haustoria appressoriis exorientia, 2-3 $\mu$ m lata, intra cellulas singulas hospitis crescentia.

Habitat parasitice inter filamenta viva protonematis musci xylophili Rhizomnium punctatum in locis humidis.
Typus: Germany. Bavaria. Upper Bavaria, southwestern surroundings of Starnberg: Gorge "Maisinger Schlucht", few meters afar from the rivulet "Maisinger Bach", ca 630 m a.s.1., 11.X.2009 Döbbeler 8918 (holotype, M).

Apothecia variable in size and form, (240-)300$600 \mu \mathrm{m}$ long and (150-)200-600(-650) $\mu \mathrm{m}$ wide, at first almost barrel-shaped (containing mature asci), later expanding apically to form a flat, rimless disc, tapering at the base, nearly colourless to yellowish, sometimes with a pink or orange tint. Excipulum tissue in the lower part with textura epidermoidea to textura globulosa, cells up to $35 \mu \mathrm{m}$ at their widest, in the upper part with textura porrecta, cells 4-8 $\mu \mathrm{m}$ wide, walls cyanophilous. Paraphyses filamentous, not ramified, thin-walled, apically often slightly enlarged and (4-)5-8(-10) $\mu \mathrm{m}$ wide. Asci 150-230 × (13-)1519(-22) $\mu \mathrm{m}$, unitunicate, cylindrical, eight-spored but one or two spores may degenerate, empty asci have slightly cyanophilous walls. Mature asci distinctly protrude above the hymenial level. Ascospores (fresh in water) (13-)14-17(-19) $\times(9.5-$ )10-13(-14) $\mu \mathrm{m}$, subglobose to ovoid or broadly ellipsoid, colourless, with one large, globose oilbody, epispore delicately rough and cyanophilous; ascospores normally uni-seriate; in lactophenolcottonblue shrinking by about $1-2 \mu \mathrm{m}$, oil-bodies becoming inconspicuous. Hyphae (2.5-)3-5(-6) $\mu \mathrm{m}$ wide, colourless, usually thin-walled, with ramifications and anastomoses, covered by a thin cyanophilous layer, intrahyphal hyphae repeatedly observed, growing on and between the protonemal filaments, forming complex infection structures consisting of appressoria, infection pegs and haustoria. Appressoria (20-)25-50(-61) $\mu \mathrm{m}$ long, 10$27(-32) \mu \mathrm{m}$ high and 21-26 $\mu \mathrm{m}$ wide, connected to the mycelium by a continuously enlarging hypha, closely attached to the infected protonemal cells, convex, elliptical in outline when seen from above, with 1 or 2(3) septa, distal walls $1.5-3(-4)$ $\mu \mathrm{m}$ thick; protonemal filaments and adjacent appressoria sometimes irregularly entangled with hyphae. Infection pegs normally one per appressorium, surrounded by a lignituber-like tube consisting of host cell wall material, tube 8-20 $\times 4-6 \mu \mathrm{m}$, with thick walls and uneven surface, straight or curved, sometimes enclosing the infecting hyphae and thus preventing haustorium formation (Fig. 3 c); host cell wall at perforation point seen from 

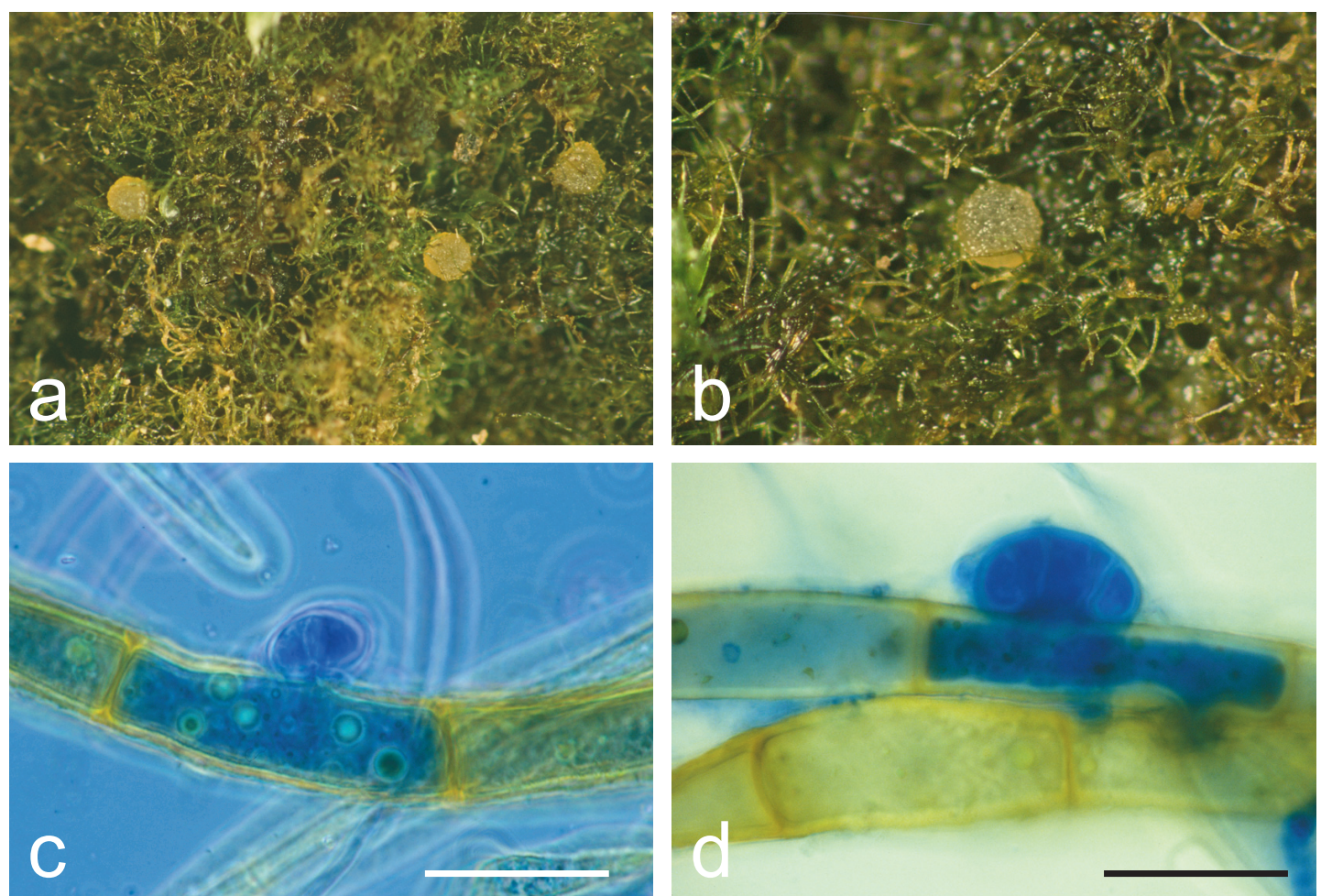

Fig. 1. Octospora mnii on Rhizomnium punctatum (holotype). $a=$ three apothecia on protonemal filaments, $b=a$ single apothecium on protonemal filaments, $\mathrm{c}, \mathrm{d}=$ infection structures consisting of appressorium, infection peg and haustorium within single cells of protonemal filaments. $-\mathrm{c}=$ phase contrast optics. $-\mathrm{c}, \mathrm{d}$ scales $=45 \mu \mathrm{m}$.

above with an elliptical cleavage (Fig. 3 b), 11-23 $\mu \mathrm{m}$ long and 6-13 $\mu \mathrm{m}$ wide (outer dimensions), host cell walls often slightly elevated at the perforation point when observed laterally. Haustoria (1-)2-3(-4) $\mu \mathrm{m}$ wide, intracellular, thin-walled, ramified, sometimes largely filling out the host cell lumen, septa missing or difficult to see, not growing through the cross walls of the protonema. Occurring on persistent, xylophilous protonema of Rhizomnium punctatum (Hedw.) T.J.Kop. (syn. Mnium punctatum Hedw.).

The parasite has been sporadically observed during the months of October and November over a period of more than ten years in the same small region from which the type collection comes. It is unknown if the species also forms ascomata during the spring or summer. There are more gorges located in Upper Bavaria and the Alps with comparable ecological conditions, which may extend the known distribution of the fungus.
Additional specimens studied: with the same data as the type collection, but: 6.XI.2001 Döbbeler 7374 (M); 1.XI.2009 Döbbeler 8919 (M); 21.XI.2009 Döbbeler 8920 (M); 6.X. 2011 Döbbeler 9402 (M); 18.X.2011 Döbbeler 9298 (TUR).

\section{Octospora mnii and its relationships}

Octospora mnii infects the Rhizomnium protonema found covering damp, decorticated trunks of fallen trees lying on the ground. Sometimes, the protonema has even begun to form shoots. Even adult plants with sporophytes have been observed on the borders of the protonemal mats. Exceptionally, single apothecia may be found in leaf axils or between rhizoids of the stems of developing plants. Infection does not visibly alter the host's appearance.

This new species belongs to the most inconspicuous members of the genus Octospora. It has 
extremely small, drably coloured, sparsely distributed ascomata that may be hidden from the observer by protonemal filaments. The more or less barrel-shaped ascomata bearing mature asci measure less than $300 \mu \mathrm{m}$ across at the widest point. The smallest observed ascoma containing asci with spores was $240 \mu \mathrm{m}$ long and $150 \mu \mathrm{m}$ wide. Outer excipulum cells, asci and paraphyses are sometimes curved inwards at the apices. Such ascomata strongly resemble the size and shape of the closed perithecioid fruit-bodies seen in Octosporella, a hepaticolous genus of ten species (Yao et al. 2006, Döbbeler 2011b).

The appressoria are the largest known amongst both the octosporaceous and non-octosporaceous bryophilous fungi. These really big hyphal appendages, with their dense cytoplasmic content, are easy to detect when coloured with lactophenol-cottonblue. Measuring up to $50 \mu \mathrm{m}$ in diam, the appressoria are larger than the entire ascomata of several of the smallest ascomycetes found on bryophytes. For example, the tiny Bryochiton perpusillus Döbbeler found growing subcuticularly on the leaves of Polytrichum Hedw. and related genera (Döbbeler 1978, Döbbeler \& Hertel 2013, Wäli et al. 2014) would completely fit into the appressoria of Octospora mnii. The forces required for hyphae to perforate the host cell walls are enormous (Brzezina 2000) and may explain the size, shape and structure of the appressoria. Exploited caulonema cells have walls up to $4 \mu \mathrm{m}$ thick. The appressoria closely adhere to the host's rhizoid walls and present a convex outer surface. The appressoria are structurally well-supported by thick outer walls and one or two internal transverse walls. Additionally, hyphae wrapped around the appressorium and the host rhizoid strengthen the whole penetration apparatus.

Octospora mnii is characterized by having tiny (less than $0.6 \mathrm{~mm}$ long), almost colourless to yellowish apothecia, subglobose ascospores measuring 14-17 × 10-13 $\mu \mathrm{m}$ with a delicately rough epispore, large, one- or two-septate appressoria up to $50 \mu \mathrm{m}$ long, and the species exerts host selection. The novel species seems to be most closely related to the following three congenerics, which also have similar sized ascospores. O. lilacina (Seaver) Svrček \& Kubička (syn. O. libussae Svrček \& Kubička) has very small, $0.3-0.8(-1.5)$ $\mathrm{mm}$ wide apothecia that have a unique, distinctly violet colour. When observed using SEM mag- nification, the epispore is seen as an irregularly patterned reticulum. The appressoria are less than half the size as those of $O$. mnii. The apothecia of O. lilacina occur between May and October and are recorded on unidentified protonemata. Döbbeler \& Itzerott (1981) illustrated appressoria and haustoria (Figs. 1, 2), Engel \& Hanf (1986) gave a colour photo of an apothecium. Benkert (1995) illustrated an ascospore by SEM (Pl. 2, Fig. 3) and discussed the species (2009). Octospora phagospora (Flageolet \& Lorton) Dennis \& Itzerott has apothecia up to $1 \mathrm{~mm}$ wide, and differs from $O$. mnii by having four-spored asci and coarsely warty ascospores (Benkert 2007, 2009, Matcham 2011). A third, similar species, Octospora similis (Kirschst.) Benkert, forms considerably larger apothecia (up to $2 \mathrm{~mm}$ wide) and infects the rhizoids of Bryum species, where it can induce galls. It has only been found in a Bryum protonemal stage once (Benkert 1996, 2009). The frequently collected and unmistakable Octospora humosa (Fr.) Dennis, with its large, vividly coloured apothecia, infects the subterranean rhizoids of Polytrichaceae. It was once observed on the persistent protonema of Pogonatum aloides (Hedw.) P.Beauv. inducing globose galls (Döbbeler \& Itzerott 1981). An instance of Lamprospora annulata Seaver on the protonema of Ephemerum minutissimum Lindb. has been reported by Eckstein \& Eckstein (2013). This species also occurs on Pleuridium Rabenh. and has characteristically ornamented ascospores (Benkert 1987).

\section{The host and its protonema}

Rhizomnium punctatum is a common species found on soil, rocks and rotting wood in moist habitats. It is widespread and frequent throughout most of Europe (Frahm 2006) and also occurs in North America, Greenland and parts of Asia (Smith 1978, Koponen 1981). The Eurasiatic distribution of $R$. punctatum was mapped by Koponen (1972), and its Siberian distribution by Koponen \& Afonina (1992).

Although not consistently mentioned in descriptions, $R$. punctatum has a persistent protonema (Smith 1978, Frahm 2006) that covers the substrate with an algal-like, brown mat. The multicellular ramified protonemal filaments are clearly differentiated into two interconnected parts: the 

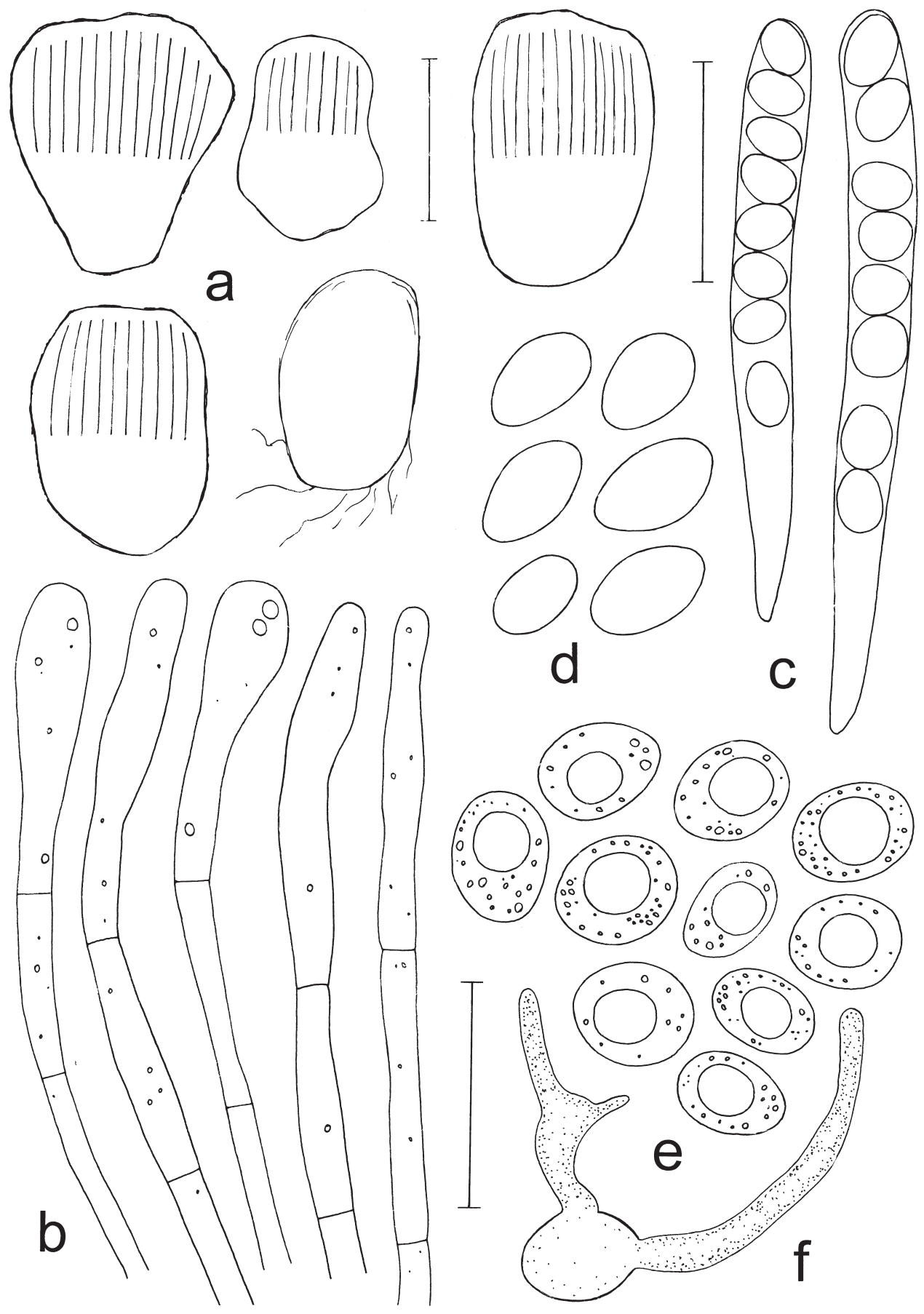

Fig. 2. Octospora mnii. $\mathrm{a}=$ small apothecia in outline, $\mathrm{b}=$ apical cells of paraphyses, $\mathrm{c}=\mathrm{asci}, \mathrm{d}$, $\mathrm{e}=\mathrm{ascospores}, \mathrm{f}=$ germinating ascospore. $-\mathrm{a}=$ holotype and $8920, \mathrm{~b}, \mathrm{c}, \mathrm{e}=8920, \mathrm{~d}, \mathrm{f}=9402 .-\mathrm{a}, \mathrm{b}, \mathrm{e}$ in tap water, $\mathrm{c}$, $\mathrm{d}$, f in lactophenolcottonblue. - a scale $=250 \mu \mathrm{m} ; \mathrm{b}, \mathrm{d}-\mathrm{f}$ scale $=30 \mu \mathrm{m}$; c scale $=60 \mu \mathrm{m}$. 
chloronema and the caulonema. Following Magill \& Stotler (1990), the primary assimilatory chloronema is photosynthetic and has green filaments, numerous chloroplasts, and short cells separated by perpendicular walls. The caulonema is the secondary, bud-generating part, characterized by reddish-brown filaments with few chloroplasts and having long cells with oblique cross walls. Octospora mnii hyphae attack both the chloronema and caulonema cells. Many Octospora species that parasitize non-protonematous mosses infect the multicellular, subterranean rhizoids of mosses. Although each of the three filament types (chloronema, caulonema, and rhizoids) has a range of distinctive attributes, they are developmentally interrelated (Duckett et al. 1998).

\section{Non-octosporaceous fungi on protonemata and Mniaceae}

The protonema of foliose bryophytes is commonly defined as the developmental stage occurring between the germination of the spore and the formation of a leafy shoot by an apical cell (Nehira 1983). Protonemata are normally short-lived and therefore provide an unsuitable source of host tissue for fungi developing complex structures, like fruit-bodies. However, the persistent protonemata of liverworts and mosses can be an appropriate substrate for fungal growth. Up to now, there are no records of fungal colonization of liverwort protonemata, but the colonization of moss protonemata by octosporaceous ascomycetes has been recorded, as indicated above. Apart from the aforementioned discomycetes, Bryonectria protonematis Döbbeler (Hypocreales) develops perithecia on the protonema-forming moss Ephemeropsis tjibodensis K.I.Goebel (Hookeriales), a phyllosphere species on vascular plants in Asia
(Döbbeler 2011a). Several rozellopsidalean parasites (Oomycota) also colonize the protonemata and/or the rhizoids of acrocarpous mosses and produce sporangia, often within gall-like hypertrophies (Martínez-Abaigar et al. 2005, Nour-ElDeen 2011).

Surprisingly, the Mniaceae are not a popular substrate for fungi, although the family comprises ten genera with 91 species (Frey \& Stech 2009, treated as Mnioideae), some of them quite frequent and widespread. Additionally, the comparatively large plants offer a potentially rich substrate, which could be advantageous for fungal colonization. The few fungal species recorded on Mnium s.l. are poorly known and in most cases only one collection exists. Information regarding these ascomycetes and anamorphic fungi on gametophytic and sporophytic tissue can be found in Wolf (1954), Racovitza (1959), Bowen (1968), and Döbbeler (1978, 1979). Hedwig (1789) described Octospora pyriformis associated with dead Mnium. Judging from his analysis and illustration, performed more than two hundred years ago, his fungal species was not operculate and has subsequently been transferred to the unitunicate genera by various authors. Kost (1988) compiled a list of bryophilous basidiomycetes and their hosts that included various species of Mnium s.l. Frequently recorded genera like Galerina Earle and Arrhenia Fr. (Agaricales) occur on many different mosses, indicating a low grade of specificity. A short treatment of the cyphelloid basidiomycete Rimbachia arachnoidea (Peck) Redhead on Mnium, including a colour photo, was given by Pegler \& Legon (1999).

Acknowledgements: We are very grateful to Dr. Dieter Benkert (Berlin) for his valuable comments on an early draft of the manuscript. We also thank Franz Höck (München) for his assistance with the photographic work. 

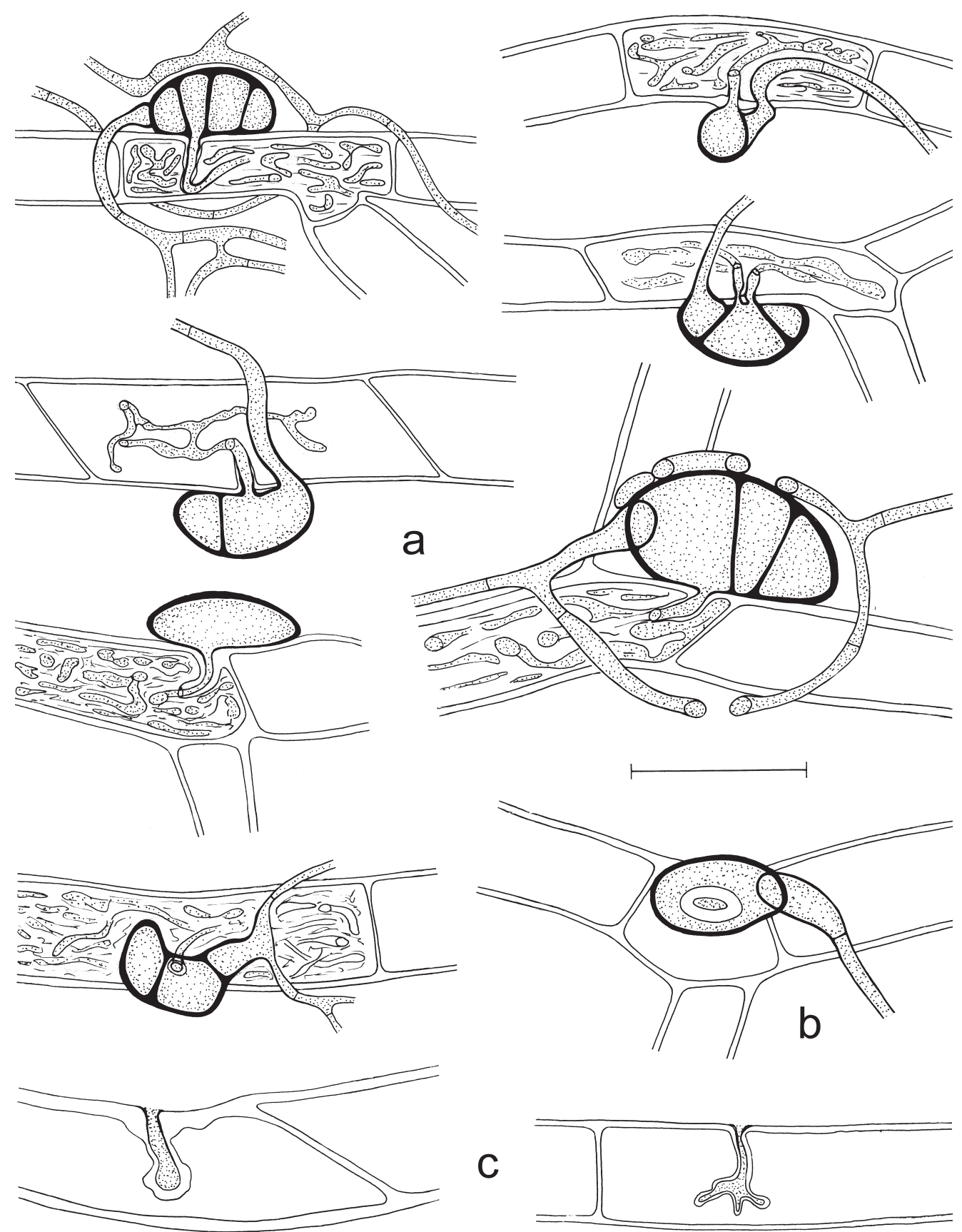

Fig. 3. Octospora mnii (holotype, in lactophenol-cotton blue). $\mathrm{a}=$ appressoria (seen laterally) attached to protonemal filaments, showing infection pegs and intracellular haustoria, $\mathrm{b}=$ appressorium seen from above, haustorium not indicated, $\mathrm{c}=$ lignituber-like structures that enclose infection pegs, appressorium not indicated. - scale $=50 \mu \mathrm{m}$. 


\section{References}

Benkert, D. 1987: Beiträge zur Taxonomie der Gattung Lamprospora (Pezizales). - Zeitschrift für Mykologie 53: 195-271.

Benkert, D. 1995: Becherlinge als Moosparasiten. - Boletus 19: 97-127.

Benkert, D. 1996: Beiträge zur Kenntnis bryophiler Pezizales-Arten. 4. Octospora similis (= O. melina). - Agarica 14: 50-57.

Benkert, D. 2007: Zur Kenntnis des Vorkommens bryophiler Pezizales (Ascomycota) in Südost-Europa. - Mycologia Montenegrina 10: 7-21.

Benkert, D. 2009: Zwei neue Arten bryophiler Pezizales (Ascomycota) aus der Bundesrepublik Deutschland und Auflistung der aus Deutschland bisher nachgewiesenen Arten mit Kurzdiagnostik. - Zeitschrift für Mykologie 75: $51-68$.

Bowen, W.R. 1968: The imperfect fungus Schizotrichella lunata on the moss Mnium cuspidatum Hedw. - Bryologist 71: 124-126.

Brzezina, A.S. 2000: Punching appressoria. - Mycological Research 104: 131-132.

Döbbeler, P. 1978: Moosbewohnende Ascomyceten I. Die pyrenocarpen, den Gametophyten besiedelnden Arten. - Mitteilungen der Botanischen Staatssammlung München 14: 1-360.

Döbbeler, P. 1979: Moosbewohnende Ascomyceten II. Acrospermum adeanum.- Mitteilungen der Botanischen Staatssammlung München 15: 175-191.

Döbbeler, P. 2011a: Bryonectria protonematis (Hypocreales) on Ephemeropsis tjibodensis, the first muscicolous ascomycete of the phyllosphere. - Nova Hedwigia 92: 369-376.

Döbbeler, P. 2011b: Two new hepaticolous species of the genus Octosporella (Pezizales). - Herzogia 24: $357-$ 365.

Döbbeler, P. \& Itzerott, H. 1981: Zur Biologie von Octospora libussae und O. humosa, zwei im Moosprotonema wachsenden Pezizales. - Nova Hedwigia 34: 127-136.

Döbbeler, P. \& Hertel, H. 2013: Bryophilous ascomycetes everywhere: Distribution maps of selected species on liverworts, mosses and Polytrichaceae. - Herzogia 26: 361-404.

Duckett, J.G., Schmid, A.M. \& Ligrone, R. 1998: Protonemal morphogenesis. - In: Bates, J.W., Ashton, N.W. \& Duckett, J.G. (eds). Bryology for the twenty-first century, 223-246. - British Bryological Society. London.

Eckstein, J. \& Eckstein, G. 2013: Bemerkenswerte Funde bryoparasitischer Pezizales (Ascomycota) aus Deutschland. - Boletus 14: 55-66.

Engel, H. \& Hanf, B. 1986: In Nordwestoberfranken gefundene Arten der Gattung Octospora Hedw. ex S.F. Gray. - Pilzflora Nordwestoberfrankens 9, A: 3-20, Pilzfarbtafel 42.
Frahm, J.-P. 2006: Mosses. - In: Frey, W., Frahm, J.-P., Fischer, E. \& Lobin, W., The liverworts, mosses and ferns of Europe. English edition revised and edited by Blockeel, T.L. - Harley Books. Colchester.

Frey, W. \& Stech, M. 2009: Marchantiophyta, Bryophyta, Anthocerotophyta. Syllabus of plant families (A. Engler's Syllabus der Pflanzenfamilien), Part 3, 13th ed. by Frey, W. - Gebr. Borntraeger. Stuttgart.

Hedwig, J. 1789: Descriptio et adumbratio microscopicoanalytica muscorum frondosorum. Tom. II: 32, tab. 10A, figs. 1-9. - Leipzig: Müller, J.G.

Koponen, T. 1972: Speciation on the Mniaceae. - Journal of the Hattori Botanical Laboratory 35: 142-154.

Koponen, T. 1981: A synopsis of Mniaceae (Bryophyta). VII. List of species and their distribution. - Annales Botanici Fennici 18: 113-115.

Koponen, T. \& Afonina, O. 1992: Miscellaneous notes on Mniaceae (Bryophyta). XV, Genus Rhizomnium in the Russia east of Ural Mts. - Bryobrothera 1: 245-250.

Kost, G. 1988: Interactions between basidiomycetes and bryophyta. - Endocytobiosis \& Cell Research 5: 287308.

Magill, R.E. \& Stotler, R.E. 1990: English bryological glossary. - In: Magill, R.E. (ed.). Glossarium polyglottum bryologiae, 1-50. - Missouri Botanical Garden. St. Louis.

Martínez-Abaigar, J., Núñez-Olivera, E., Matcham, H.W. \& Duckett, J.G. 2005: Interactions between parasitic fungi and mosses: pegged and swollen-tipped rhizoids in Funaria and Bryum. - Journal of Bryology 27: 47-53.

Matcham, H. 2011: Octospora phagospora: a bryophilous fungus new to Britain. - Field Bryology 105: 37.

Nehira, K. 1983: Spore germination, protonema development and sporeling development. - In: Schuster, R.M. (ed.). New manual of bryology, Vol. I: 343-385. - Hattori Botanical Laboratory. Nichinan.

Nour-El-Deen, S. 2011: Rostellopsid (chytrid) galls on Fissidens rhizoids. - Journal of Bryology 33: 82-84.

Pegler, D.N. \& Legon, N.W. 1999: Profiles of Fungi. 103. Rimbachia arachnoidea. - Mycologist 13: 85.

Racovitza, A. 1959: Étude systématique et biologique des champignons bryophiles. - Mémoires du Muséum National d'Histoire Naturelle, Série B, Botanique 10 (fasc. 1): 1-288; pl. 1-84.

Smith, A.J.E. 1978: The moss flora of Britain and Ireland. - Cambridge University Press. Cambridge.

Wäli, P.P., Huhtinen, S, Pino-Bodas, R. \& Stenroos, S. 2014. Three common bryophilous fungi with meristematic anamorphs and phylogenetic alliance to Teratosphaeriaceae, Capnodiales. - Fungal Biology, http:// dx.doi.org/10.1016/j.funbio.2014.08.007.

Wolf, F.A. 1954: An undescribed fungus on moss capsules. - Bryologist 57: 188-189.

Yao, Y.-J., Spooner, B.M. \& Læssøe, T. 2006: Octosporella fusispora sp. nov. (Pezizales), with a key to the species of the genus. - Nova Hedwigia 82: 483-487. 